\title{
The Effect of Storage on the Efficacy of Eugenia Aromatica (Baill.) in the control of Callosobruchus Maculatus (Fabricius) (Coleoptera: Bruchidae) Pest. ${ }^{1}$ OFUYA, T.I;. ${ }^{2}$ OLOTUAH O. F.; ${ }^{1}$ AKINYOADE, D.O.
}

${ }^{1}$ Department of Crop, Soil and Pest Management, The Federal University of Technology, P.M.B. 704, Akure, Nigeria

${ }^{2}$ Department of Plant Science \& Biotechnology, Adekunle Ajasin University, Akungba-Akoko, Nigeria.

\begin{abstract}
The effect of storage on the efficacy of powders from Eugenia aromatica (Baill.) of different ages in the control of Callosobruchus maculatus (Fabricius), a major pest of stored cowpea seeds, were investigated in the laboratory. Powders stored for periods of $<1$ month, 24, 36 and 48 months with particle size of $300 \mu \mathrm{m}$ were tested. Contact toxicity was tested for the differently aged powders at $0.4 \mathrm{~g}$ of material per $20 \mathrm{~g}$ of seed in separate plastic Petri plates. In fumigant toxicity tests $20 \mathrm{~g}$ of infested cowpea seeds was suspended in a piece of muslin cloth, over $0.4 \mathrm{~g}$ of powder in a container. In the contact toxicity tests, all the differently aged powders killed $C$. maculatus adult within 48 hours. The differently aged powders significantly $(\mathrm{P}<0.05)$ reduced oviposition by the introduced $C$. maculatus adults and adults did not emerge from eggs laid. In the fumigant toxicity test, first use of the differently aged powders prevented emergence of adult $C$. maculatus from fumigated eggs. In a consecutive reuse of powders, adults emerged from fumigated eggs but the numbers were significantly $(\mathrm{P}<0.05)$ fewer than in the control. In conclusion, the shelf-life of E. aromatica powder as a bruchicide is at least four years. @ JASEM
\end{abstract}

The cowpea seed beetle, Callosobruchus maculatus (F.) is a cosmopolitan pest of stored grain legumes, especially cowpeas, Vigna unguiculata (L.) Walp., in the tropics and subtropics (Ofuya, 2001). Severely damaged seeds are disfigured with egg covers and riddled with adult exit holes, and consequently have reduced weight and poor germiability. Often, after six months in storage $100 \%$, seed infestation may be recorded (Alabeek, 1996, Ogunkoya and Ofuya, 2001). A substantial part of world cowpea production comes from Nigeria with about 4 million hectares and approximately 1.7 million tonnes of beans annually (Ofuya, 2003). Cowpea seeds contain a high amount of protein and B-vitamins (Phillips and $\mathrm{M}$. C. Waiters, 1991) and help to prevent starvation among low resource farmers and poor urban population (Quin, 1997). Many conventional insecticidal dusts such as pirimiphos methyl, and permethrin, and fumigants such as Aluminium phosphide had been reported to be effective against C. maculatus in storage. However rising prices and infrastructural problems impose considerable restrictions to their use, moreover, synthetic insecticides involve risks for human health and the environment especially when improperly used which may be common among uneducated rural farmers in Africa (Ofuya, 2003). Since the last three decades, plant-derived insecticides have been vigorously investigated worldwide, as possible replacement for the synthetic insecticides in stored products protection (Lale, 2001). Plant products such as vegetable oils, essential oils, volatile oils, crude extracts and powders have been tested against C. maculatus, ( Lale, 1995, Dales, 1996, Golob et al, 1999, Boeke et al. 2001). Dry powder made from neem seeds, Azadirachta indica, A. Juss, buds of Clove tree, Eugenia aromatica, Baill., fruits of West African brown Pepper, Piper guineense, Schum and Thonn., Seeds of "pepper fruit" tree, Dennetia tripetala Baker and root bark of the "tooth ache plant", Zanthozylum zanthozyloides (Lam.) Waterm., applied at 2\% of the weight of stored beens will effectively control the cowpea seed beetle in storage (Lale, 1994, Ogunwolu and ldowu, 1994; Ogunwolu and Odunlami, 1996; Adedire and Lajide, 2001, Ofuya and Salami, 2002). 1t is not known for how long these insecticidal powders will remain effective after preparation. These study investigated aspects of the shelf-life of E. aromatica dry flower buds powder against $C$. maculatus.

\section{MATERIALS AND METHODS}

C. maculatus culture and experimental conditions: The C. maculatus used was derived from a colony originating from infested cowpea seeds collected from a local market in Akure, Nigeria. The colony has been maintained in Kilner jars in an open laboratory $(28 \pm 30 \mathrm{C}$ and $70 \pm 5 \%$ relative humidity) for more than 60 generations, using Ife Brown cowpea as substrate. All experiments were carried out in the open laboratory.

Preparation of E. aromatica powder: E. aromatica dry flower buds were purchased in local herbal stores in markets in Ondo State, Nigeria. The identity was confirmed at The Herbarium, Department of Botany, Obafemi Awolowo University, Ile-1fe, Nigeria. The flower buds were further oven dried to a constant weight at a temperature of $400^{\circ} \mathrm{C}$. Thereafter, the dried buds were ground in 1.5 HP kitchen mill (model KOAHLBACH). The resulting powder was then sieved to a particle size of $300 \mu \mathrm{m}$ with a British laboratory test standard sieve (serial number 133032). E. aromatica powder had been prepared 
at different times in this manner since January 2000. The powders prepared at different times of a given particle size were kept in separate plastic containers with lightly fitted lids and placed in a wooden cupboard in the open laboratory.

Contact toxicity of differently aged E. aromatica powders to $C$. maculatus: The differently aged powders of E. aromatica were tested at $0.4 \mathrm{~g}$ of material per $20 \mathrm{~g}$ of seed in separate plastic Petri plates $(8.5 \mathrm{~cm}$ diameter $)$. The selected rate of application has been generally recommended for insecticidal plant powders (Lale, 1995) and has been found to be effective against $C$. maculatus (Adedire and Lajide, 2001). Ten couples (twenty individuals) of C. maculatus (aged 1-2 days old) were introduced into each plate which was shaken. Adult mortality was monitored in 48 hours and thereafter all insects were removed. The numbers of eggs laid by the female beetles on the seeds were then counted. The numbers of adults which emerged from these eggs were also counted as from three weeks after introducing the beetle couples unto the seeds. There was a control treatment involving no addition of plant powder onto seeds. Each treatment including the control was replicated three times.

Fumigant toxicity of differently aged E. aromatica powders to C. maculatus: Fumigant effect of each of the differently aged $E$. aromatica powders on freshly laid eggs $(<24$ hours $)$ and larvae of $C$. maculatus was determined. Each powder was tested at $0.4 \mathrm{~g}$ against 300 fresh eggs contained in $20 \mathrm{~g}$ of seed. The selected rate of application of $E$. aromatica has been found to be effective for fumigating C. maculatus eggs (Longe, 2004). Infested cowpea seeds were suspended in a piece of muslin cloth, over the powder in a container. The container lid was properly screwed up to hold the muslin cloth and the cowpea seeds in space, and also make the set up airtight. There was a control with no powder in the container. All treatments were replicated thrice. Number of adults that emerged from treated eggs and larvae was counted. In another experiment, the same E. aromatica powders which had been used to fumigate $C$. maculatus eggs were immediately reused to fumigate $20 \mathrm{~g}$ of seed bearing $300 \mathrm{C}$. maculatus eggs as described previously. Number of adults that emerged from the second set of treated eggs was similarly counted.

Data analysis: Data collected were subjected to analysis of variance (ANOVA). Whilst egg counts were subjected to square root transformation, percentages were arcsine transformed, before analysis.

\section{RESULTS AND DISCUSSION}

Summary of data recorded and analyzed when ten couples of $C$. maculatus were introduced unto $20 \mathrm{~g}$ of Ife Brown cowpea seeds and shaken with $0.4 \mathrm{~g}$ of E. aromatica powder of different ages is presented in Table 1. Irrespective of age of powder, all introduced adult beetles were killed in 48 hours. No adults were killed within 48 hours in the control treatment. Significantly greater $(\mathrm{P}<0.05)$ numbers of eggs were laid by the beetles in the control within 48 hours than in other treatments. Number of eggs laid by beetles in treatments involving use of the differently aged E. aromatica powders was not significantly different $(\mathrm{P}>0.05)$ from each other. Table I also shows that percentage adult emergence from eggs laid by the introduced beetles was significantly higher $(\mathrm{P}<0.05)$ in the control than in other treatments. No adults emerged from eggs in treatments involving use of the differently aged powders.

Table 1: Parameters measured when ten couples of C. maculatus were introduced into $20 \mathrm{~g}$ of cowpea seeds and shaken with $0.4 \mathrm{~g}$ of E. aromatica powder of different ages.

\begin{tabular}{|c|c|c|c|}
\hline Age of E. aromatica powder & $\begin{array}{l}\% \text { C. maculatus adult mortality in } \\
48 \text { hours } \pm \text { SE }\end{array}$ & $\begin{array}{l}\text { Number of eggs laid by introduced } \\
\text { females } \pm \mathrm{SE}\end{array}$ & $\begin{array}{l}\% \text { adult emergence from eggs } \\
\text { laid } \pm \text { SE }\end{array}$ \\
\hline Less than 1 month & $100.0 \pm 0.00(90.0)$ & $5.3 \pm 0.33(2.6)$ & $0.0 \pm 0.00(0)$ \\
\hline 24 months & $100.0 \pm 0.00(90.0)$ & $7.3 \pm 0.33(2.9)$ & $0.0 \pm 0.00(0)$ \\
\hline 36 months & $100.0 \pm 0.00(90.0)$ & $9.3 \pm 2.40(3.2)$ & $0.0 \pm 0.00(0)$ \\
\hline 48 months & $100.0 \pm 0.00(90.0)$ & $6.0 \pm 0.00(2.7)$ & $0.0 \pm 0.00(0)$ \\
\hline Control (no powder) & $\begin{array}{lll}0.0 & 0.00 & (0)\end{array}$ & $301.3 \pm 32.39(17.3)$ & $65.5 \pm 3.96(54.0)$ \\
\hline $\operatorname{LSD}(0.05)$ & & 37.18 & 4.53 \\
\hline
\end{tabular}

Figures in parentheses are transformed values

* Corresponding author: ${ }^{2}$ Olotuah O. F. 
Table 2: Percentage of $C$. maculatus adults that emerged from two batches of seeds bearing beetle eggs and fumigated with $0.4 \mathrm{~g}$ of differently aged $E$. aromatica powders on two successive occasions

\begin{tabular}{llc}
\hline Age of $E$. aromatica powder & $\begin{array}{l}\% \text { adult emergence from eggs first fumigated } \\
\text { with powder } \pm \mathrm{SE}\end{array}$ & $\begin{array}{l}\text { \% adult emergence from eggs fumigated with } \\
\text { previously used powder } \pm \mathrm{SE}\end{array}$ \\
\hline Less than 1 month & $0.0 \pm 0.00(0)$ & $5.6 . \pm 0.70(13.6)$ \\
24 months & $0.0 \pm 0.00(0)$ & $20.5 \pm 1.47(26.9)$ \\
36 months & $0.0 \pm 0.00(0)$ & $33.1 \pm 2.06(35.1)$ \\
48 months & $0.0 \pm 0.00(0)$ & $63.8 \pm 1.82(53.0)$ \\
& $79.1 \pm 0.77(62.8)$ & 4.02 \\
Control (no powder) & 0.88 & \\
\hline
\end{tabular}

Figures in parentheses are arcsine transformed values

Table 2 shows percentage of $C$. maculatus adults that emerged from two batches of seeds bearing beetle eggs and fumigated with $0.4 \mathrm{~g}$ of differently aged E. aromatica powders on two successive occasions. In first fumigation percentage adult emergence was significantly higher $(\mathrm{P}<0.05)$ in the control treatment than in other treatments involving the differently aged powders. No adults emerged from eggs in treatments involving use of the differently aged powders. In the second fumigation, percentage adult emergence was significantly higher $(\mathrm{P}<0.05)$ in the control treatment than in other treatments involving the immediate reuse of the differently aged powders. The less than one month old E. aromatica powder reduced percentage adult emergence more significantly during reuse than other powders.

The results of this study have corroborated reports of previous workers (Adedire and Lajide, 2001; Longe, 2004) that $E$ aromatica powder has significant contact and fumigant action against $C$. maculatus. The mechanisms of its protective action against the cowpea seed beetle include direct toxicity to adults and eggs, and inhibition of oviposition by female beetles. More importantly, it was observed that E. aromatica powder still manifested significant contact and fumigant insecticidal activity against the cowpea seed beetle four years after the dry flower buds was powdered. An important factor in the retention of insecticidal action of these powders may have been proper packaging (plastic containers with tightly fitted lids) which may have prevented escape of the active ingredients. Good packaging and storage have long been known to be vital in preserving and maintaining activity of chemical insecticides (Pedigo, 1991). The possibility of reuse of a given quantity of $E$. aromatica powder for fumigation of C. maculatus eggs is an added advantage this * Corresponding author: ${ }^{2}$ Olotuah O. F. botanical. It was observed that the same freshly prepared powder (less than one month old) can be reused immediately after first use and still cause significant mortality of $C$. maculatus eggs and consequently reduction in adult emergence and damage to seeds. The effectiveness of reuse of powder however decreased significantly with the age of powder. The possibility of reuse of a given quantity of $E$. aromatica powder for fumigation suggests that the toxic vapours may be released slowly. The most widely used chemical fumigant for infested cowpeas in Nigeria is perhaps aluminium phosphide. The fumigation tablets emit toxic phosphine gas $\left(\mathrm{PH}_{3}\right)$ on contact with the moist atmosphere in a sealed grain store (Hassall, 1990). The same tablet cannot be reused a second time. Information that is usually provided in pesticide and in fact all drug labels is time of production or manufacture and time in which the chemical will become ineffective in performing its normal function. The sale and use of adulterated and expired pesticides are part of the problems militating against pesticide use in Nigeria (Ogunwolu et al., Okunade, 2001). A casual perusal of labels on synthetic pesticides sold in Nigeria will reveal that the active material in most expires in three to five years. The shelf life of Eugenia powder (four or probably more years) therefore compares favourably with that of many synthetic insecticides. This is very important if $E$. aromatica powder becomes formulated into insecticidal dusts that will be marketed and sold for use.

\section{REFERENCES}

Adedire, C O; Lajide L (2001). Efficacy of powders of some tropical plants in the control of the pulse beetle, Callosobruchus maculatus 
(F.) (Coleoptera: Bruchidae). Appl. Trop. Agric. 6: 11-15.

Alebeek, F A N van (1996). Natural suppression of bruchid pests in stored cowpea (Vigna unguiculata (L.) Walp.) in West Africa. Inter.J. Pest Management 42: 55-60.

Boeke, S L; Loon van, J J A; Huis van, A; Kossou, D K; Dicke , M (2001). The use of plant material to protect stored leguminous seeds against seed beetles: a review. 108 pp. Backhuys Publishers, The Netherlands.

Dales, M J (1996). A review of plant materials used for controlling insect pests of stored products. NRI Bulletin 65, Chatham, UK: Natural Resources Institute.

Golob, P; Moss, C; Males, M; Fidgen, A; Evans, J (1999). The use of spices and medicinals as bioactive protectants for grains. 239 pp. FAO, Rome.

Hassall, K A (1990). The Biochemistry and Uses of Pesticides. 2nd Edition. Macmillan Press Ltd, London. 536 pp.

Lale, N E S (1994). Laboratory assessment of the effectiveness and persistence of powders of four spices on cowpea bruchid and maize weevil in airtight facilities. Sam. J. Agric.Res.II: 79-84.

Lale, N E S (1995). An overview of the use of plant products in the management of stored product Coleoptera in the tropics. PostHarvest News and information 6: $69 \mathrm{~N}-75 \mathrm{~N}$.

Lale, N E S (2001). The impact of storage insect pests on post-harvest losses and their management in the Nigerian agricultural system. Nig. J. Exp. and App.Biol.2: 231-239.

Longe, O O (2004). Fumigant toxicity of some botanical powders to eggs and larvae of Callosobruchus maculatus (F) (Coleoptera: Bruchidae). M. Agric. Tech. Thesis, The Federal University of Technology, Akure, Nigeria.

Ofuya, T 1 (2001). Biology, ecology and control of insect pests of stored legumes in Nigeria, pp.
24-58, in Pests, of Stored Cereals and Pulses in Nigeria: Biology, Ecology and Control, Edited by T.1 Ofuya and N.E.S. Lale, Dave Collins Publication, Nigeria.

Ofuya, T I (2003). Beans, insects and man. Inaugural Lecture Series 35, The Federal University of Technology, Akure, Nigeria.45 pp.

Ofuya, T I; Salami, A (2002). Laboratory evaluation of different powders from Dennetia tripetala Bak., as protectant against damage to stored seeds of cowpea by Callosobruchus maculatus (F.). J. Sust. Agric.\& the Environ. 4 (I): 36-41.

Ogunwolu, O; Idowu, O (1994). Potential of powdered Zanthoxylum zanthoxyloides (Rutaceae) root bark and Azadirachta indica (Meliaceae) seed for control of the cowpea seed bruchid, Callosobruchus maculatus (Bruchidae) in Nig. J. Afric. Zool.108: 521528.

Ogunwolu, E O; Odunlami, A T (1996). Suppression of seed bruchid (Callosobruchus maculatus F.) development and damage on cowpea (Vigna unguiculata (L.) Walp.) with Zanthoxylum zanthoxyloides (Lam.) Waterm. (Rutaceae) root bark powder when compared with neem seed powder and pirimiphos methyl. Crop Protec. 15: 603-607.

Ogunwolu, E O; Igoli, J O; Longs, N N (1998). Reduction in reproductive fitness of Callosobruchus maculatus F. exposed to Zanthoxylum zanthozyloides (Lam.) Waterm. J. Her. Spi. and Med. Plants 6: 19-27.

Pedigo, L P (1991). Entomology and Pest Management. Macmillan Publishing Co.,New York. 646 pp.

Phillips, R D; McWatters, K H (1991). Contribution of cowpea to nutrition and health. Food Tech. 45: 127-130.

Quin, F M (1997). Introduction, pp. ix-xv, in Adv.in Cowpea Res., Edited by B.B. Singh, D.R. Mohan- Raj., K.E. Dashiell and L.E.N. Jackai. IITA and JIRCAS. 